\title{
BORON INCREASES THE VIABILITY OF HUMAN CANCER AND MURINE FIBROBLAST CELLS AFTER LONG TIME OF CRYOPRESERVATION
}

\author{
Taha Bartu HAYAL \\ Department of Genetics and Bioengineering, Faculty of Engineering, Yeditepe University, Istanbul, TURKEY \\ Cite this article as: \\ Hayal T.B. 2020. Boron Increases the Viability of Human Cancer and Murine Fibroblast Cells After Long Time of Cryopreservation. Trakya Univ J \\ Nat Sci, 21(2): 115-122, DOI: 10.23902/trkjnat.758920
}

Received: 29 June 2020, Accepted: 26 August 2020, Online First: 16 September 2020, Published: 15 October 2020

Edited by:

Reşat Ünal

*Corresponding Author:

Taha Bartu Hayal

bartu.hayal@yeditepe.edu.tr

\section{ORCID ID:}

orcid.org/0000-0003-1369-2715

Key words:

Boron

Cryopreservation

Cryoprotective agents

Cancer cells

Fibroblast cells

\begin{abstract}
Through the process of cryopreservation, cells are stored at very low temperature for a long time to decrease the biological and chemical reactions in viable cells. In this process, the administration of cryoprotective agents is crucial since cryopreservation is regarded as a leading process in various research fields such as biotechnology, clinical medicine and maintenance of both animal and plant cells. Even after a long time of storage in very low temperatures, a recovery is achieved by cryo-preservative agents that act on cellular metabolism and biophysiology of cells. In the current study, the effect of boron on cryopreservation of human lung cancer cell line, A549, and murine fibroblast cell line, L929, was investigated with the help of cell viability assay, colony forming unit assay and RT-PCR analysis. $15 \mu \mathrm{g} / \mathrm{ml}$ boron supplemented freezing medium was found to indicate a positive effect on cell viability. Moreover, gene expression profiles of A549 and L929 cell lines have been altered. The levels of apoptosis related genes decreased while proliferation related gene levels increased significantly after repeated freeze-thaw cycles or long period of freezing. As indicated through our results, sodium pentaborate pentahydrate, as a boron source, might be a crucial cryoprotective agent for cryo-protection and bio-banking of cancer and healthy cells while keeping their viability and functionality.
\end{abstract}

Özet: Canlı hücrelerin uzun süre boyunca çok düşük sıcaklıklarda saklanması işlemi kriyokorunma olarak adlandırılır. Kriyo-koruma işlemi biyoteknoloji, klinik çalışmalar ve hayvan veya bitki hücreleriyle ilgili birçok çalışmada çok önemli bir rol oynadığından dolayı, kriyo-korumada kullanılan ajanların araştırılması son derece mühimdir. Kriyo- koruma ajanları, hücresel metabolizma ve biyofizyoloji üzerindeki etkileri nedeniyle uzun süreli kriyo-korumanın ardından hücresel canlılığın korunmasını sağlarlar. Mevcut çalışmada; hücre canlılık testi, koloni oluşturma testi ve gerçek zamanlı polimeraz zincir reaksiyonu tekniklerinden yararlanılarak, borun kriyokoruma üzerindeki etkisi, insan akciğer kanser hücre hattı, A549 ve fare fibroblast hücre hatt1, L929 kullanılarak araştırılmıştır. Hücre dondurma ortamını $15 \mu \mathrm{g} / \mathrm{ml}$ bor ile desteklemenin hücre canlılığı üzerine olumlu etki ettiği gözlemlenmiştir. Ayrıca, tekrar eden dondurma - çözme döngüleri ve uzun süreli kriyo-koruma sonucunda, gen anlatım profilleri değişen A549 ve L929 hücre hatlarının, bor takviyesi sonrasında, programlı hücre ölümüyle alakalı genlerinin anlatımında azalma, hücre çoğalması ile ilgili genlerinde de artış gözlemlenmiştir. Sonuçlarımız göstermiştir ki bor kaynağı olarak sodium pentaborat pentahidrat, kanser veya sağlıklı hücrelerin canlılıklarını kaybetmeksizin dondurulmalarını ve hücrelerin uzun süreli saklanmaları için son derece önemli bir kriyo-koruyucu ajan olarak kullanılabilir.

\section{Introduction}

Cryopreservation is a process that is used to store cells for a long period of time at very low temperature which reduces the biological and chemical reactions in viable cells (Pegg 2007). Cryopreserved cells are in the state called suspended animation which refers to decreasing biological functions of the cells to keep them in fine structure for desired period of time (Mazur 1970, Asfar et al. 2014, Sambu 2015). Nevertheless, due to water-to-ice transition, the formation of extra- and intracellular ice crystals can be mortal for living cells (Mazur 1970, Karlsson \& Toner 1996, Pegg 2007). The freezing rate of the cells is important since slow cooling results in osmotic alterations caused by formed ice crystals or hypertonic medium. However, fast cooling causes an increase in intracellular ice formation (Jang et al. 2017). To overcome these limitations, freezing medium is supplied with cryoprotective agents to control water transport, nucleation and ice crystal formation (Jang et al. 2017). 
Cryoprotective agents should possess some properties such as being biologically acceptable, being able to penetrate into the cell and being low toxic (Jang et al. 2017). With the purpose of maintaining the best survival rate of cells, the sample volume, cooling rate, warming rate and cryoprotective agent concentrations are required to be modified concerning different cell types (Yavin \& Arav 2007). Therefore, optimizing the cryopreservation procedures by using effective cryoprotective agents is fundamental to reduce freeze-thaw stress.

Boron is an abundant mineral that plays a critical role in microorganisms (Tanaka \& Fujiwara 2008), plants (Warington 1923), animals (Park et al. 2005, Hu et al. 2014) and humans (Clarke et al. 1987, Park et al. 2005). Previous studies showed that cell wall and membrane unity of plant cells is disrupted due to the lack of boron suggesting that boron is involved in membrane integrity (Dordas \& Brown 2005). Furthermore, several studies demonstrated that boron is a key player in wound healing as well as in cellular proliferation (Blech et al. 1990, Dogan et al. 2014, Demirci et al. 2015, Demirci et al. 2016). Boron was also demonstrated as a potential cryoprotective agent in mesenchymal stem cells (Demirci et al. 2014) and semen (Yeni et al. 2018) culture systems. In this study, sodium pentaborate pentahydrate $(\mathrm{NaB})$ was used as a boron source to investigate the effects of boron on cryopreservation of human lung carcinoma cell line, A549, and murine fibroblast cell line, L929. Thus, the use of $\mathrm{NaB}$ aims to develop an advanced method that offers a decrease in the adverse effects of long-term cryopreservation and freeze-thaw procedures.

\section{Materials and Methods}

\section{Cell Lines}

A549 and L929 cell lines were purchased from ATCC (American Type Culture Collection, Rockville, MD). Dulbecco's Modified Eagle's Medium (DMEM, Gibco, UK) which was supplemented with $10 \%$ fetal bovine serum (FBS, Gibco, UK) and $1 \%$ Penicillin/Streptomycin/Amphotericin (PSA, Gibco, UK), was used as a culture medium for both cell lines. Cells were incubated in humidified incubator at $37^{\circ} \mathrm{C}$. Atmospheric conditions were adjusted as $5 \% \mathrm{CO}_{2}$. Cells were de-attached from the surface with the help of $0.25 \%$ trypsin-EDTA (Gibco, UK). Additionally, cells were kept in growth phase at all times by controlling the confluence less than $80 \%$.

\section{Freeze-Thaw Cycles}

Freeze-Thaw cycles were conducted to determine any potential cryoprotective effect of $\mathrm{NaB}$ on A549 and L929 cells. Freezing procedure was conducted as described previously with minor alterations (Demirci et al. 2014). Briefly, cells were trypsinized and counted with hemocytometer. $10^{6}$ cells were suspended in $1 \mathrm{ml}$ freezing medium (90\% FBS, 10\% DMSO) with or without 15 $\mu \mathrm{g} / \mathrm{ml} \mathrm{NaB}$ supplementation. Cells were cryopreserved in $2 \mathrm{ml}$ cryo-vials. The cryo-vials were frozen in Nalgene
Mr. Frosty (Thermo Fisher, Waltham, MA, USA) to ensure gradually freezing at $-80^{\circ} \mathrm{C}$. After 24 hours, frozen cells were transferred to $-196^{\circ} \mathrm{C}$ liquid nitrogen tank. Thawing was performed by increasing the temperature to $37^{\circ} \mathrm{C}$ immediately to reduce harmful effects of dimetilsulfoxide ( $\mathrm{Me}_{2} \mathrm{SO}$, DMSO). Viable cells were counted after each thaw. Cell viability test was conducted by using trypan blue (T-8154, Sigma-Aldrich) and a hemocytometer. The cryo-preservative effect of $\mathrm{NaB}$ was determined by two different experimental designs, shortterm and long-term cryopreservation. Routine cell culture conditions and cell banking for extended period of time were mimicked by short-term and long-term freeze-thaw cycles, respectively. Thawing procedure was performed after 1 day or 6 months after each cycle for short-term and long-term cryopreservation, respectively. Following each thawing, cells were cultured up to $80 \%$ confluency before they were subjected to another freezing cycle.

\section{Colony Forming Unit (CFU) Assay}

Alterations in colony-forming capability caused by freeze-thaw cycle were determined via CFU assay (Digirolamo et al. 1999). After each thaw, A549 and L929 cells were plated in six-well plates (Corning, NY) as 300 cells/well. Culture medium was changed in every 48 hours with fresh growth medium (10\% FBS, 1\% PSA containing DMEM high glucose) for 15 days. Formed colonies were fixed by using $4 \%$ paraformaldehyde and stained with crystal violet. ZEISS microscopy system with AxioCam ICc 5 camera and ZEN2 (blue edition) application was used to take pictures.

\section{Real Time PCR Assay}

Distinguishing primers for Beta actin ( $\beta$-actin), Caspase-3, Caspase-7, B-cell lymphoma 2 (BCL2), Myelocytomatosis (C-MYC), Nuclear Factor Kappa B (NFKB), P53, Ubiquitin Specific Protease 7 (USP7) were designed by using the Primer-BLAST software (National Center for Biotechnology, USA) and Sentegen (Turkey) synthesized the primers. Relative gene expression levels were determined by SYBR Green method (Navarro et al. 2015). Briefly, $5 \mu$ l of PowerUp ${ }^{\text {TM }}$ SYBR ${ }^{\text {TM }}$ Green Master Mix (Thermo-Fisher, USA) was supplied with $1.5 \mu \mathrm{l}$ $\mathrm{dH}_{2} \mathrm{O}, 1 \mu \mathrm{l}$ primer and $2.5 \mu \mathrm{l}$ cDNA for each well of 96well PCR plate. RT-PCR conditions were applied by using RT-PCR system (Bio-Rad, Hercules, CA).

\section{Statistical Analysis}

All experiments were conducted at least three times. Normality assumptions were checked using Shapiro-Wilk test by using GraphPad Prism 7 software. Statistical analyses were conducted using one-way ANOVA and Tukey's post hoc test by using GraphPad Prism 7 software. Statistical significance was determined as $\mathrm{P}<0.05$.

\section{Results}

NaB supplementation protects A549 and L929 cells in cryopreservation process

To identify the effect of $\mathrm{NaB}$ on repetitive freeze-thaw cycles, trypan blue staining was conducted. A549 and L929 
cells were frozen and thawed for four times, repetitively, and viable cells were counted and compared. Results showed that after first freeze-thaw viable A549 and L929 cells were increased by 1.5 and 3 fold, respectively (Fig. 1A). Moreover, cryopreservation media supplemented with $15 \mu \mathrm{g} / \mathrm{ml} \mathrm{NaB}$ increased the cell viability of A549 cells by 2.5 fold after second freeze-thaw cycle in which viability of L929 cells were observed to be increased by 3 fold (Fig. 1B). Similarly, increased profile of cell viability was noticed in both A549 (1.4 fold) and L929 (2 fold) cells after third cycle (Fig. 1C). However, the most remarkable results were obtained after fourth freeze-thaw cycle. Cell viability of A549 cells increased by 4 fold and L929 cells by 3.3 fold (Fig. 1D).
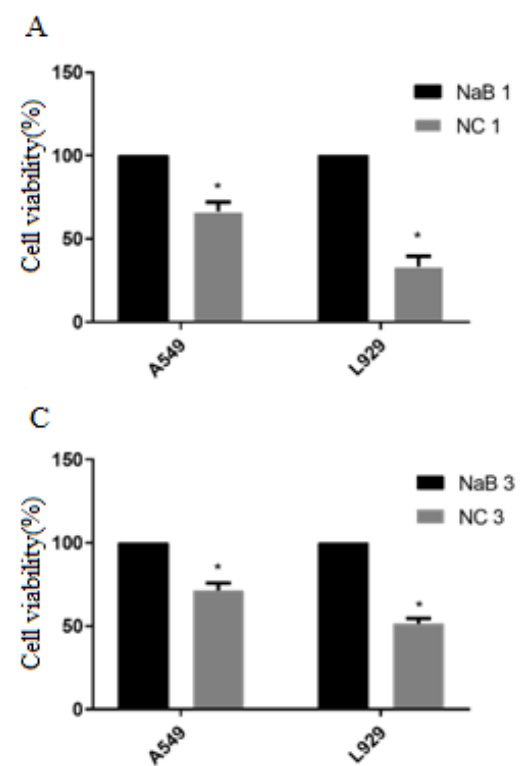

NaB supplemented cryopreservation medium alters colony forming capacity of A549 and L929 cells

CFU assay was conducted to determine the possible changes in colony forming capacity of A549 and L929 cells after short term freeze-thaw cycles. Obtained results demonstrated that the amount of A549 colonies doubled after $\mathrm{NaB}$ addition to cryopreservation media (Fig. 2A-B). Furthermore, dramatically bigger colonies were noticed in $\mathrm{NaB}$ included cryopreservation group (Fig. 2C). However, there was no significant change observed in number of L929 colonies between control and $\mathrm{NaB}$ groups (Fig. 2D-E). Also, no significant change was detected in diameter of L929 colonies after short term cryopreservation (Fig. 2F).
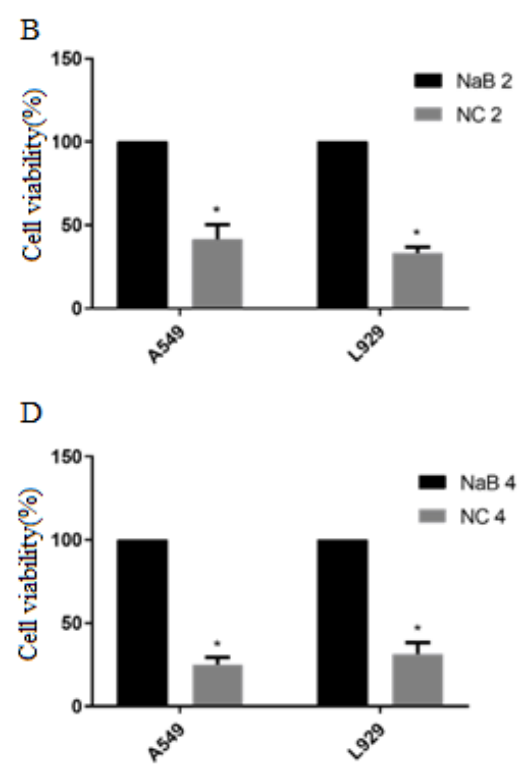

Fig. 1. NaB decreases the harmful effects of freeze-thaw cycles on viability of A549 and L929 cell lines. $10^{6}$ cells were suspended in $1 \mathrm{ml}$ freezing medium with or without $15 \mu \mathrm{g} / \mathrm{ml} \mathrm{NaB}$ supplementation. Cell viability analysis was conducted after first (A), second (B), third (C) and fourth (D) freeze-thaw cycles. NC: Negative control, NaB: sodium pentaborate pentahydrate, $\mathrm{P}<0.05$.

NaB supplemented cryopreservation medium changes gene expression profiles of A549 and L929 cell lines

To investigate the effect of $\mathrm{NaB}$ supplemented cryopreservation medium on gene expression profiles of A549 and L929 cell lines, RT-PCR assay was performed. A549 and L929 cells were frozen and thawed for four times and after each thaw, alterations in CASP3, CASP7, BCL2, C-MYC, NFKB and P53 gene expression levels were determined. Fig. 3 demonstrates that after the first freeze thaw cycle, expression levels of BLC2 gene dramatically increased in both A549 (12.6 fold) and L929 (3.5 fold). Approximately, 2-fold increase was observed in BCL2, CMYC and NFKB expression levels in A549 cell line after the second freeze-thaw cycle. Similarly, expression levels of C-MYC ( 2 fold) and NFKB (2.3 fold) genes increased in L929 cells after the second freeze-thaw cycle. Additionally, after the second cycle, CASP3 gene expression level was found to be 4.6 and 5.99 fold decreased in A549 and L929 cells, respectively. After the third cycle, BCL2 and C-MYC expression levels of A549 cells increased by 10 fold and 8.9 fold, respectively. 5 fold increase in NFKB gene expression level was observed in L929 cell line after the third cycle. Last freeze thaw cycle with $\mathrm{NaB}$ supplemented media, resulted in a significant drop in P53 gene expression (27.7 fold) compared to the control group. Also increased CMYC gene expression (2 fold) was observed in L929 cells after the fourth freeze-thaw cycle with $\mathrm{NaB}$ supplementation (Fig. 3).

NaB supplemented freezing media prevents A549 and L929 cells from long term cryo-damage

In addition to the short-term freeze-thaw cycles, the long term cryo-preservative effect of $\mathrm{NaB}$ supplementation was also investigated in A549 and L929 cells. Frozen cells were transferred into liquid nitrogen tank for 6 months and after that time, all experiments which were conducted for short-term freeze-thaw cycles, were replicated. Obtained results showed that, after long term cryopreservation, cell viability of A549 cells increased (5 fold) with $\mathrm{NaB}$ supplementation (Fig. 4A). Similarly, long term storage with regular freezing media resulted in a significant decrease $(71.5 \%)$ in cell viability 
of L929 cells compared to $\mathrm{NaB}$ including freezing media (Fig. 4B). After 6 months at $-196^{\circ} \mathrm{C}$, colony forming capacity of A549 cell line was found to be increased with $\mathrm{NaB}$ added freezing media (Fig. 4C). The amount of A549 colonies nearly doubled after $\mathrm{NaB}$ supplementation (Fig. 4D) and diameters of the colonies increased by $26.8 \mathrm{~mm}$ (Fig. 4E). Yet, there was no significant different observed in L929 colony forming capacity (Fig. 4F), the amount of colonies (Fig. 4G) and diameter of colonies (Fig. 4H). Furthermore, 4 fold increase in C-MYC gene expression

A.
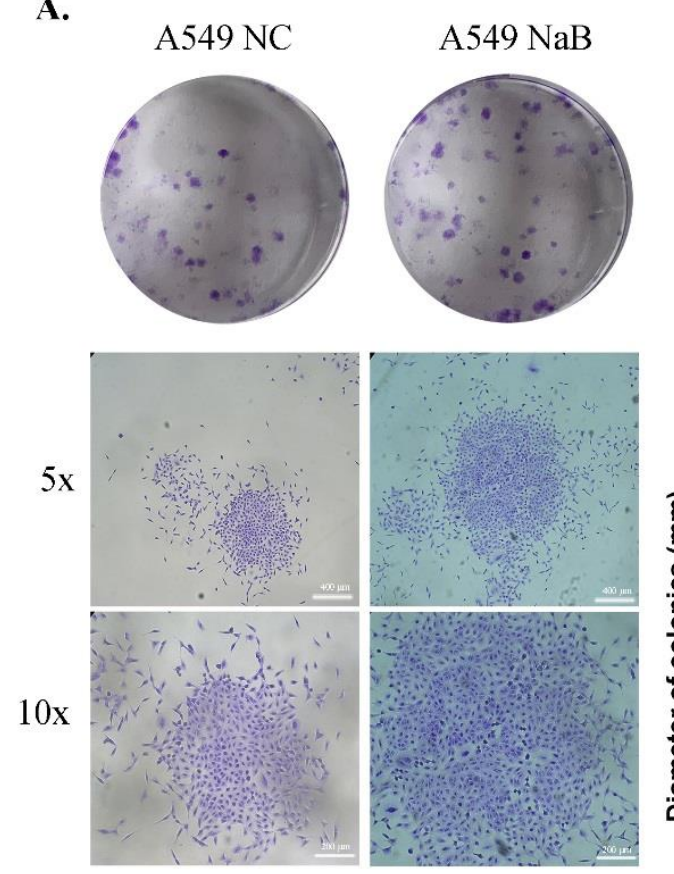

D.

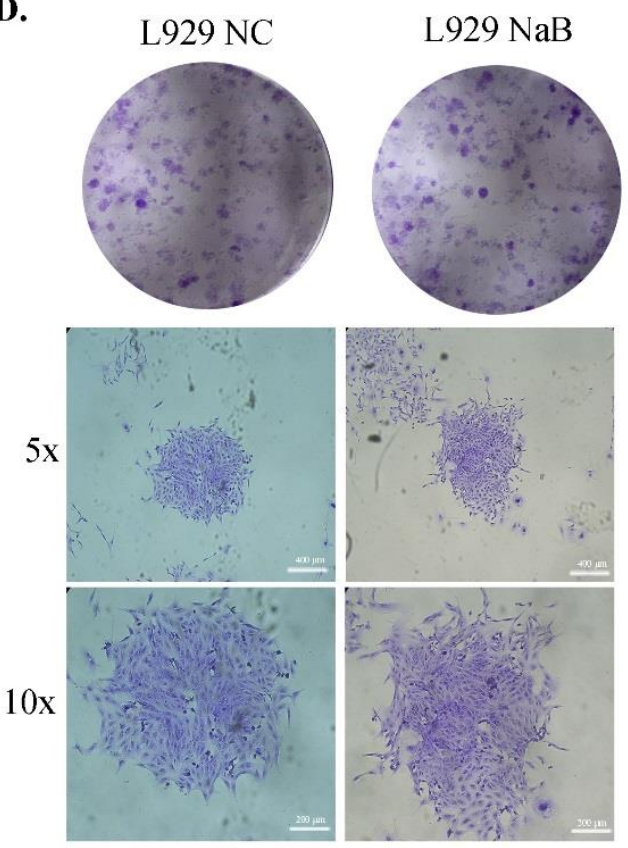

was observed in A549 cell line (Fig. 4I). Additionally, the expression levels of CASP3 and CASP7 genes in A549 cell line decreased by 37 -fold and 48 -fold, respectively (Fig. 4I). A significant decrease in CASP3 (10-fold) and CASP7 (5.2-fold) gene expressions was also observed in L929 cell line (Fig. 4J). Moreover, after long-term cryopreservation of $\mathrm{L} 929$ cell line with the $\mathrm{NaB}$ supplemented freezing media, BCL2 and P53 expression levels were found to be increased by 2 fold and 3.5 fold, respectively (Fig. 4J).

B.
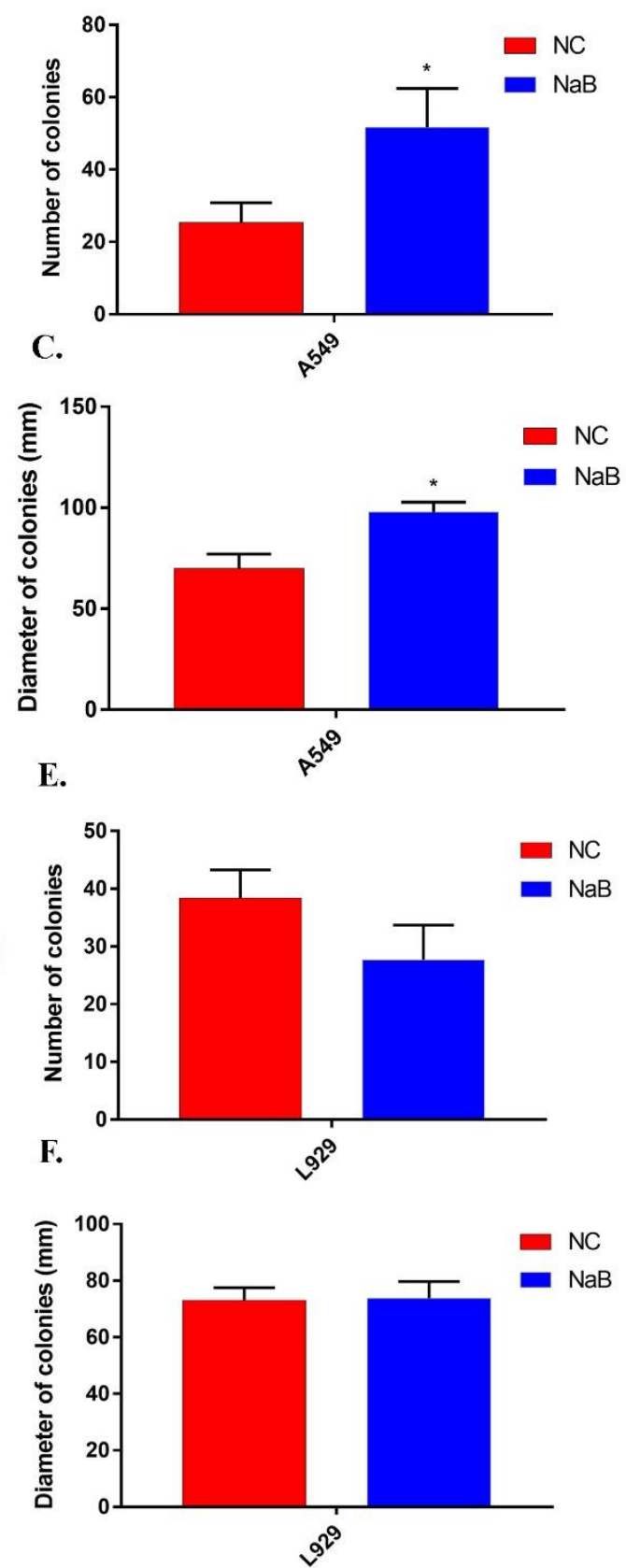

Fig. 2. $\mathrm{NaB}$ supplemented cryopreservation medium protects the colony forming ability of A549 and L929 cell lines. $15 \mu \mathrm{g} / \mathrm{ml}$ of $\mathrm{NaB}$ supplementation increased the capability of colony formation of A549 cell line (A) in terms of number (B) and diameter (C) of colonies. There was no significant change detected in the colony formation ability of L929 cell line (D) as similar amount (E) and size of colonies (F) was observed. NC: Negative control, NaB: sodium pentaborate pentahydrate, $\mathrm{P}<0.05$. 

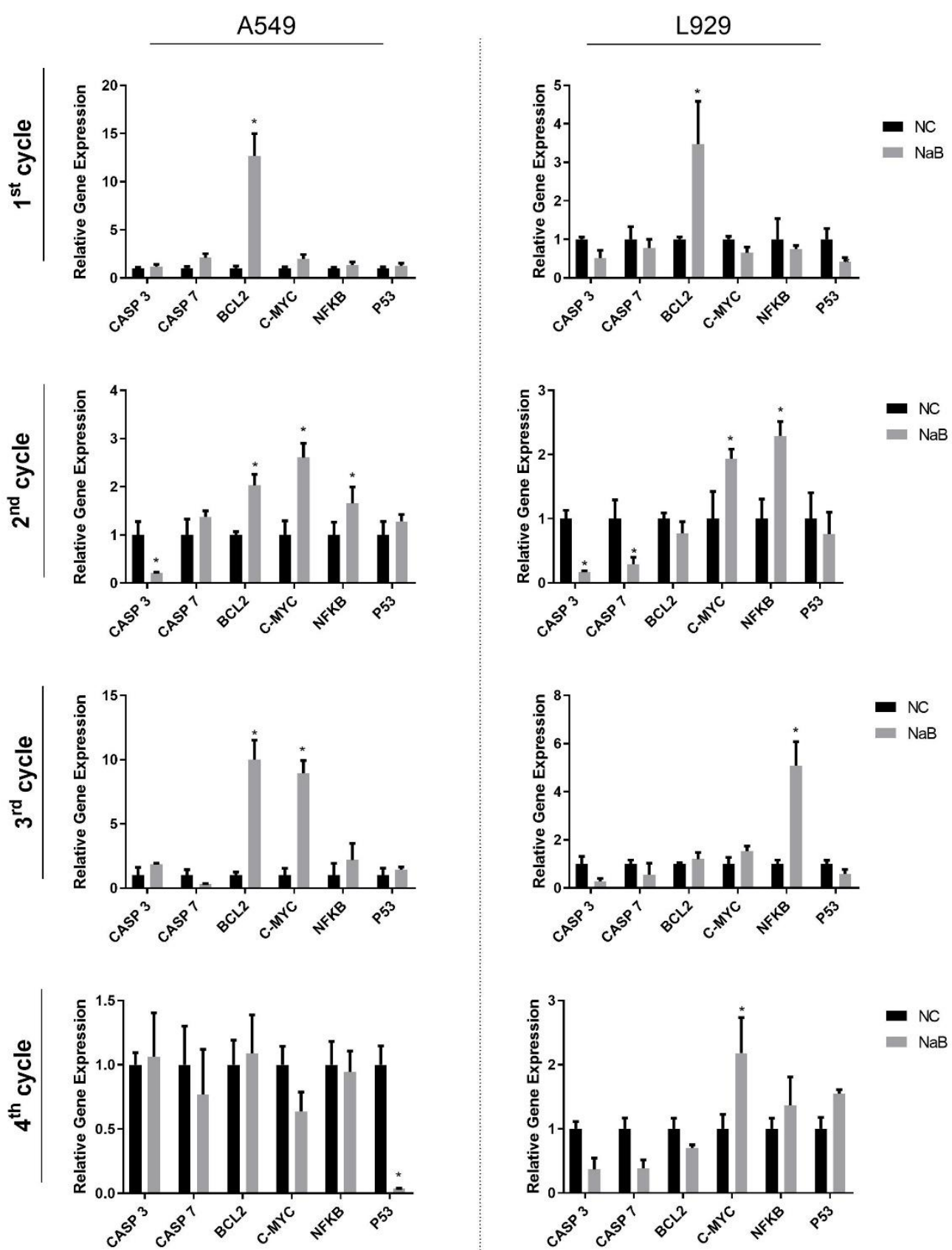

Fig. 3. NaB supplemented freezing medium alters the proliferation or apoptosis related gene expressions of A549 and L929 cell lines after each freeze-thaw cycle. NC: Negative control, NaB: sodium pentaborate pentahydrate, CASP3: Caspase 3, CASP7: Caspase 7, BCL2: B-cell lymphoma 2, C-MYC: Cellular myelocytomatosis, NFKB: Nuclear factor kappa B, P<0.05.

\section{Discussion}

Cryoprotective agents have several vital roles in the cryopreservation process which can be considered as one of the most important technologies in different research areas such as biotechnology, clinical medicine and maintenance of animal and plant cells. The multiple effects of these agents on cellular metabolism and biophysiology of cells provide a recovery with functionality even after long time of cryopreservation in very low temperatures (Elliott et al. 2017). Previous studies identified boron as a possible cryoprotective agent for cryopreservation of stem cells (Demirci et al. 2014) and semen (Yeni et al. 2018). The cryoprotective effect of boron may be related to its ability to protect integrity and functionality of the membrane along with its interactions with ions to balance osmatic pressure (Park et al. 2004, Henderson et al. 2009). It is known that the type and the amount of cryoprotective agents might differ according to the cryopreserved cell type (Yavin \& Arav 2007). Therefore, here we identify boron as a potential cryoprotective agent for human lung cancer cell line, A549, and murine fibroblast cell line, L929. 
A.

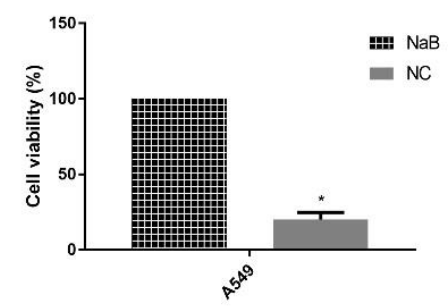

c.
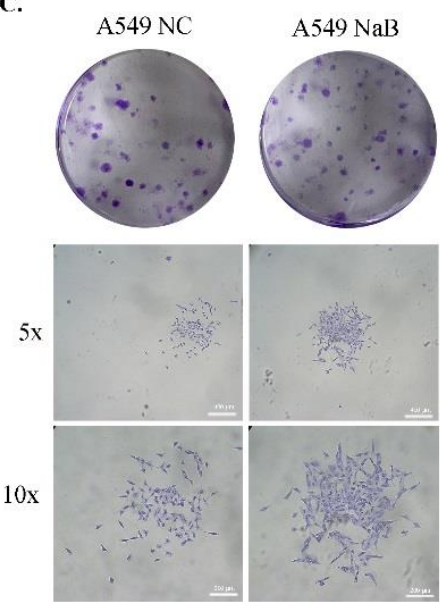

F.

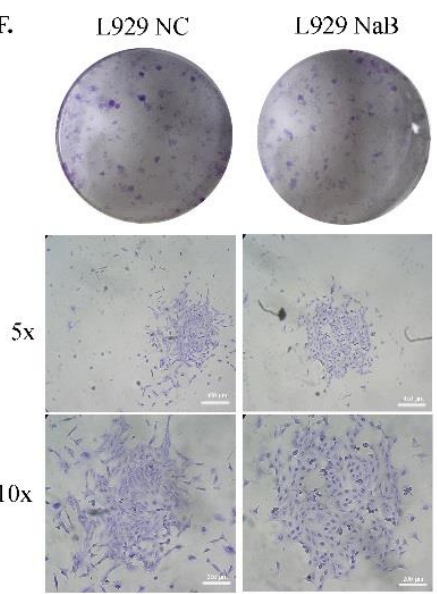

I.

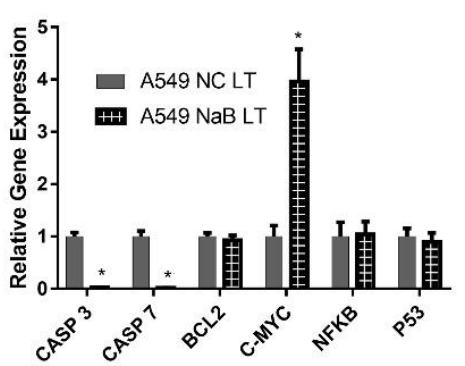

B.

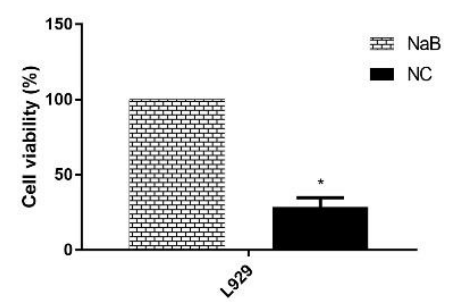

D.
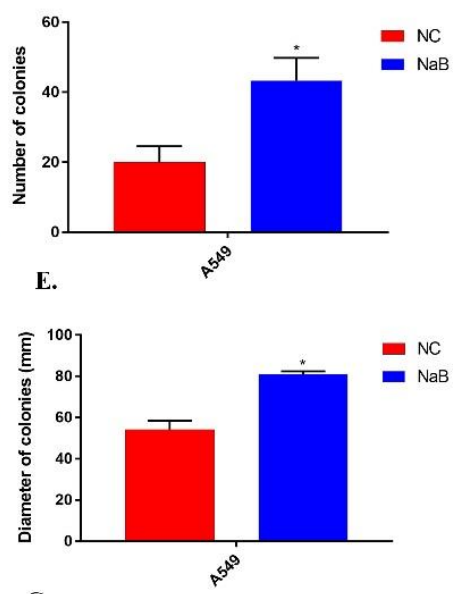

G.

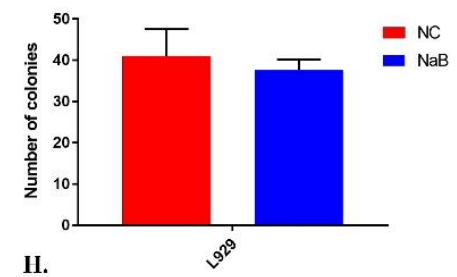

H.

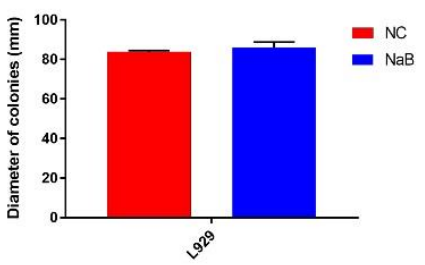

J.

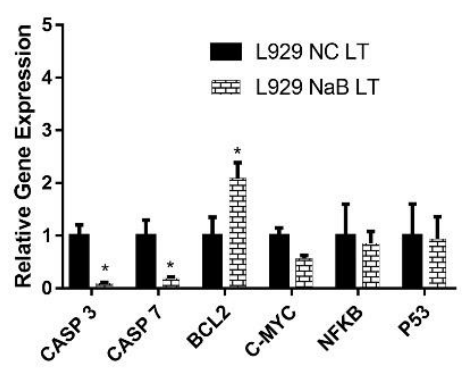

Fig. 4. As a cryoprotective agent, $\mathrm{NaB}$ protects A549 and L929 cell lines from harmful effects of long term freezing at $-196^{\circ} \mathrm{C}$. Cell viability of A549 (A) and L929 (B) cell lines was significantly increased by NaB supplementation after 6 months of cryopreservation. (C) Alterations in colony formation capacity of A549 cell line. The number (D) and diameter (E) of A549 colonies increased due to addition of $\mathrm{NaB}$ into cryopreservation medium. (F) Colony formation capacity of L929 cell line after cryopreservation with or without $15 \mu \mathrm{g} / \mathrm{ml} \mathrm{NaB}$ supplemented freezing medium. There was no significant change observed in the amount $(\mathrm{G})$ and diameter $(\mathrm{H})$ of $\mathrm{L} 929$ colonies after long-term cryopreservation. $\mathrm{NaB}$ supplemented freezing medium changes the proliferation/apoptosis related gene expressions of A549 (I) and L929 (J) cell lines after 6 months of freezing. NC: Negative control, NaB: sodium pentaborate pentahydrate, CASP3: Caspase 3, CASP7: Caspase 7, BCL2: B-cell lymphoma 2, C-MYC: Cellular myelocytomatosis, NFKB: Nuclear factor kappa $\mathrm{B}, \mathrm{P}<0.05$. 
Previous studies demonstrated that boron supplemented cryopreservation medium significantly increases the cell viability of mesenchymal stem cells after freeze-thaw cycles (Demirci et al. 2014). Our results showed similar effects of boron on cell viability of A549 and L929 cell lines. The viable numbers of A549 and L929 cells were found to be significantly increased by the freezing medium supplemented with boron after short term freeze-thaw cycles. A similar effect of boron on cell viability was also observed even after long time cryopreservation of A549 and L929 cells as well. CFU result of A549 cell line also supports our results on cell viability. However, we observed no significant change in CFU assay of L929 cell line since CFU assay is used to detect stem cell products in the culture (Pamphilon et al. 2013). It is known that freezethaw cycles alter the gene expression profiles of cells (Caliskan et al. 2014). Our RT-PCR analysis revealed that $\mathrm{NaB}$ addition increases the expression levels of proliferation-related genes in both A549 and L929 cell lines. The expression levels of BCL2, C-MYC and NFKB were found to be increased in both A549 and L929 cell lines during freeze-thaw cycles. It is known that $\mathrm{Bcl} 2$, an anti-apoptotic protein, can interact with $\mathrm{C}$ Myc and NFkB transcriptional pathways to increase proliferation and survival (Braun et al. 2013). Similarly, after long period of freezing, gene expression level of BCL2 was found to be increased in L929 cell line. Moreover, c-Myc as an essential protein for cell proliferation and reduction of apoptosis (Dang 1999) was found to be increased in A549 cell line after long term of cryopreservation with $\mathrm{NaB}$ supplemented medium. Furthermore, apoptosis related gene expression levels were found to be dramatically decreased in A549 and L929 cell lines after short term

\section{Reference}

1. Asfar, P., Calzia, E. \& Radermacher, P. 2014. Is pharmacological, H(2)S-induced 'suspended animation' feasible in the ICU? Critical Care, 18(2): 215. doi: $10.1186 / \mathrm{cc} 13782$

2. Blech, M.F., Martin, C., Borrelly, J. \& Hartemann, P. 1990. Treatment of deep wounds with loss of tissue. Value of a 3 percent boric acid solution. Presse Medicale, 19(22): 1050-1052.

3. Braun, F., de Carne Trecesson, S., Bertin-Ciftci, J. \& Juin, P. 2013. Protect and serve: Bcl-2 proteins as guardians and rulers of cancer cell survival. Cell Cycle, 12(18): 2937-2947. doi: 10.4161/cc.25972

4. Caliskan, M., Pritchard, J.K., Ober, C. \& Gilad, Y. 2014. The effect of freeze-thaw cycles on gene expression levels in lymphoblastoid cell lines. PLoS One, 9(9): e107166. doi: 10.1371/journal.pone.0107166

5. Cardona, M., Lopez, J.A., Serafin, A., Rongvaux, A., Inserte, J., Garcia-Dorado, D., Flavell, R., Llovera, M., Canas, X., Vazquez, J. \& Sanchis, D. 2015. Executioner caspase-3 and 7 deficiency reduces myocyte number in freeze-thaw cycles with boron supplementation. Gene expression level of P53 which is a vital protein for control of apoptosis (Fridman \& Lowe 2003) is decreased after the fourth freeze-thaw cycle in A549 cell line. Additionally, expression levels of Caspase 3 and 7 that are identified as executioner caspases (Cardona et al. 2015) were found to be decreased dramatically in both A549 and L929 cell lines after short term freezethaw cycles. Long term cryopreservation of A549 and L929 with $\mathrm{NaB}$ supplemented freezing medium also resulted in a significant decrease of Caspase 3 and 7 expression profiles.

\section{Conclusion}

Taken together, our results indicate that $\mathrm{NaB}$, as a boron source, may be a very important cryoprotective agent for cryo-protection and bio-banking of cancer and healthy cells without losing their viability and functionality. The impact of boron on cryopreservation of various cell types should be further investigated to reveal the exact molecular mechanism of boron on cellular metabolism at low temperatures. Additionally, combination and comparison of different cryoprotective agents with boron should be investigated especially on highly sensitive cell lines such as embryonic stem cells and oocytes.

\section{Acknowledgement}

The current study was supported by Yeditepe University. The authors are thankful for the comments and suggestions of Fikrettin Şahin (Yeditepe University, Department of Genetics and Bioengineering) and Ayşegül Doğan (Yeditepe University, Department of Genetics and Bioengineering) on the study. The authors claim that no conflict of interest exists.

the developing mouse heart. PLoS One, 10(6): e0131411. doi: 10.1371/journal.pone.0131411

6. Clarke, W.B., Webber, C.E., Koekebakker, M. \& Barr, R.D. 1987. Lithium and boron in human blood. Journal of Laboratory and Clinical Medicine, 109(2): 155-158.

7. Dang, C.V. 1999. c-Myc target genes involved in cell growth, apoptosis, and metabolism. Molecular and Cellular Biology, 19(1): 1-11. doi: 10.1128/mcb.19.1.1

8. Demirci, S., Dogan, A., Aydin, S., Dulger, E.C. \& Sahin, F. 2016. Boron promotes streptozotocin-induced diabetic wound healing: roles in cell proliferation and migration, growth factor expression, and inflammation. Molecular and Cellular Biochemistry, 417(1-2): 119-133. doi: 10.1007/s11010-016-2719-9

9. Demirci, S., Dogan, A., Karakus, E., Halici, Z., Topcu, A., Demirci, E. \& Sahin, F. 2015. Boron and Poloxamer (F68 and F127) Containing hydrogel formulation for burn wound healing. Biological Trace Element Research, 168(1): 169-180. doi: 10.1007/s12011-015-0338-Z

10. Demirci, S., Dogan, A., Sisli, B. \& Sahin, F. 2014. Boron increases the cell viability of mesenchymal stem cells 
after long-term cryopreservation. Cryobiology, 68(1): 139-146. doi: 10.1016/j.cryobiol.2014.01.010

11. Digirolamo, C.M., Stokes, D., Colter, D., Phinney, D.G., Class, R. \& Prockop, D.J. 1999. Propagation and senescence of human marrow stromal cells in culture: a simple colony-forming assay identifies samples with the greatest potential to propagate and differentiate. British Journal of Haematology, 107(2): 275-281. doi: 10.1046/j.1365-2141.1999.01715.x

12. Dogan, A., Demirci, S., Caglayan, A.B., Kilic, E., Gunal, M.Y., Uslu, U., Cumbul, A. \& Sahin, F. 2014. Sodium pentaborate pentahydrate and pluronic containing hydrogel increases cutaneous wound healing in vitro and in vivo. Biological Trace Element Research, 162(1-3): 72-79. doi: 10.1007/s12011-014-0104-7

13. Dordas, C. \& Brown, P.H. 2005. Boron deficiency affects cell viability, phenolic leakage and oxidative burst in rose cell cultures. Plant and soil, 268(1): 293-301.

14. Elliott, G.D., Wang, S. \& Fuller, B.J. 2017. Cryoprotectants: A review of the actions and applications of cryoprotective solutes that modulate cell recovery from ultra-low temperatures. Cryobiology, 76: 74-91. doi: 10.1016/j.cryobiol.2017.04.004

15. Fridman, J.S. \& Lowe, S.W. 2003. Control of apoptosis by p53. Oncogene, 22(56): 9030-9040. doi: 10.1038/sj.onc.1207116

16. Henderson, K., Stella, S.L., Kobylewski, S. \& Eckhert, C.D. 2009. Receptor activated $\mathrm{Ca}(2+)$ release is inhibited by boric acid in prostate cancer cells. PLoS One, 4(6): e6009. doi: 10.1371/journal.pone.0006009

17. Hu, Q., Li, S., Qiao, E., Tang, Z., Jin, E., Jin, G. \& Gu, Y. 2014. Effects of boron on structure and antioxidative activities of spleen in rats. Biological Trace Element Research, 158(1): 73-80. doi: 10.1007/s12011-014-98995

18. Jang, T.H., Park, S.C., Yang, J.H., Kim, J.Y., Seok, J.H., Park, U.S., Choi, C.W., Lee, S.R. \& Han, J. 2017. Cryopreservation and its clinical applications. Integrative Medicine Research, 6(1): 12-18. doi: 10.1016/j.imr.2016.12.001

19. Karlsson, J.O. \& Toner, M. 1996. Long-term storage of tissues by cryopreservation: critical issues. Biomaterials, 17(3): 243-256. doi: 10.1016/0142-9612(96)85562-1

20. Mazur, P. 1970. Cryobiology: the freezing of biological systems. Science, 168(3934): 939-949. doi: 10.1126/science.168.3934.939
21. Navarro, E., Serrano-Heras, G., Castano, M.J. \& Solera, J. 2015. Real-time PCR detection chemistry. Clinica Chimica Acta, 439: 231-250. doi: 10.1016/j.cca.2014.10.017

22. Pamphilon, D., Selogie, E., McKenna, D., CancelasPeres, J.A., Szczepiorkowski, Z.M., Sacher, R., McMannis, J., Eichler, H., Garritsen, H., Takanashi, M., van de Watering, L., Stroncek, D. \& Reems, J.A. 2013. Current practices and prospects for standardization of the hematopoietic colony-forming unit assay: a report by the cellular therapy team of the Biomedical Excellence for Safer Transfusion (BEST) Collaborative. Cytotherapy, 15(3): 255-262. doi: 10.1016/j.jcyt.2012.11.013

23. Park, M., Li, Q., Shcheynikov, N., Muallem, S. \& Zeng, W. 2005. Borate transport and cell growth and proliferation. Not only in plants. Cell Cycle, 4(1): 24-26. doi: 10.4161/cc.4.1.1394

24. Park, M., Li, Q., Shcheynikov, N., Zeng, W. \& Muallem, S. 2004. $\mathrm{NaBC} 1$ is a ubiquitous electrogenic $\mathrm{Na}+$ coupled borate transporter essential for cellular boron homeostasis and cell growth and proliferation. Molecular Cell, 16(3): 331-341. doi: 10.1016/j.molcel.2004.09.030

25. Pegg, D.E. 2007. Principles of cryopreservation, 39-57 Cryopreservation and Freeze-Drying Protocols, Springer, 39-57 pp.

26. Sambu, S. 2015. A Bayesian approach to optimizing cryopreservation protocols. PeerJ, 3: e1039. doi: 10.7717/peerj.1039

27. Tanaka, M. \& Fujiwara, T. 2008. Physiological roles and transport mechanisms of boron: perspectives from plants. Pflügers Archiv-European Journal of Physiology, 456(4): 671-677.

28. Warington, K. 1923. The effect of boric acid and borax on the broad bean and certain other plants. Annals of Botany, 37(148): 629-672.

29. Yavin, S. \& Arav, A. 2007. Measurement of essential physical properties of vitrification solutions. Theriogenology, 67(1): 81-89. doi: 10.1016/j.theriogenology.2006.09.029

30. Yeni, D., Avdatek, F. \& Gundogan, M. 2018. The effect of boron addition on spermatological parameters, oxidative stress and DNA damage after frozen-thawed process in ramlic ram semen. Kocatepe Veterinary Journal, 32(1): 53-57. 